\title{
Namjera studiranja učenika različitog rezidencijalnog podrijetla - kapitali i simbolička vrijednost obitelji i zajednica odrastanja*
}

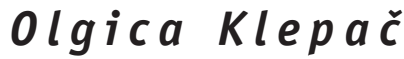

\author{
Zagreb, Hrvatska \\ e-mail:olga.soc@gmail.com
}

\begin{abstract}
SAŽETAK Za učenike iz ruralnih sredina obrazovanje je jedan od glavnih mehanizama uzlazne društvene i geografske mobilnosti. Istraživanja u zemljama s velikim ruralnim područjima, uz demografske i ekonomske, bilježe i dinamične obrazovne trendove. Usporedbe učenika iz ruralnih i urbanih područja prema različitim obrazovnim ishodima ukazuju na to da učenici iz ruralnih sredina imaju niže aspiracije i rezultate na testovima, te u manjem broju upisuju četverogodišnje studije i diplomiraju. Ipak, pitanje doprinosi li ruralnost i kako nejednakim obrazovnim mogućnostima ostaje otvoreno. Osnovni je cilj rada u hrvatskom kontekstu ispitati razlike u obrazovnim namjerama i orijentacijama učenika različitog rezidencijalnog podrijetla. Nadalje, problematizira se uloga ruralnosti u potrazi za mogućim objašnjenjima pronađenih razlika. Okvir Bourdieuove teorije prakse, koji čine koncepti kulturnog, socijalnog, ekonomskog kapitala te habitusa i polja, proširen je interesom za prostorne nejednakosti obrazovnih mogućnosti s obzirom na rezidencijalno podrijetlo učenika. Poseban naglasak stavlja se na ispitivanje simboličke vrijednosti koju za učenike ima, uz obiteljski i školski kontekst, kontekst zajednice odrastanja. Rad obuhvaća deskriptivnu i usporednu analizu (hi-kvadrat, t-test) podataka sakupljenih u proljeće 2014. godine na reprezentativnom uzorku maturanata trogodišnjih i četverogodišnjih srednjih škola regije Slavonije $(\mathrm{N}=$ 439). Analize su potvrdile pretpostavljene urbano-ruralne razlike u namjeri studiranja i obrazovnim orijentacijama, razinama dostupnog kulturnog i ekonomskog kapitala, a potvrdio se i različit značaj konteksta odrastanja i školovanja za učenike različitog rezidencijalnog podrijetla.
\end{abstract}

Ključne riječi: rezidencijalno podrijetlo, obrazovne mogućnosti, urbano-ruralne razlike, učenički kapitali, simbolička vrijednost obitelji/zajednica odrastanja.

Rad je dio izrade doktorske teze Rezidencijalno podrijetlo učenika i izbor studija u sklopu projekta Socijalni identiteti, pristup visokom obrazovanju i odabir studija 


\section{Uvod}

U zemljama s velikim ruralnim područjima (Kanada, Australija, SAD), uz demografske (smanjenje broja radno sposobnih i starenje populacije) i ekonomske (povećanje siromaštva ruralnih područja i razlike u standardu života u odnosu na urbana područja), istraživanja bilježe i dinamične obrazovne trendove (Hertzog i Pittman, 1995.). Usporedbe učenika iz ruralnih i urbanih sredina s obzirom na njihove obrazovne ishode ukazuju na to da učenici iz ruralnih sredina imaju niže aspiracije i rezultate na testovima, te ih manje upisuje četverogodišnje studije i diplomira (Bracken, 2007.; Hu, 2003.). U kontekstu izgrađivanja suvremenih društava kao društava znanja koja trebaju visokokvalificiranu radnu snagu i postavljaju zahtjeve za širenjem pristupa visokom obrazovanju, to postavlja pitanje o utjecaju ruralnosti na ulazak u visoko obrazovanje i o obrazovnim mogućnostima učenika različitog rezidencijalnog podrijetla.

Istraživanja nejednakosti u obrazovanju konzistentno potvrđuju vezu obrazovnih postignuća i društvenog podrijetla učenika, odnosno održavanje nejednakih obrazovnih mogućnosti različitih društvenih slojeva unatoč procesima masifikacije visokog obrazovanja (Puzić i Košutić, 2015.). No odluka o visokom obrazovanju kod učenika ruralnih sredina obilježena je određenim specifičnostima, njima odlazak na studij znači i geografsku i (često) društvenu mobilnost. Za učenike iz ruralnih područja obrazovanje je jedan od glavnih mehanizama uzlazne društvene i geografske mobilnosti, te njihove odluke o visokom obrazovanju imaju i sociokulturne i geografske aspekte s posljedicama i na osobnoj (društvena mobilnost i razvoj osobnog kapitala) i na društvenoj razini (prosperitet zajednica i razvoj regija).

Fokus je rada na ispitivanju razlika između učenika različitog rezidencijalnog podrijetla na elementima njihovih obrazovnih ishoda i orijentacija te dostupnih resursa $i$ simboličke vrijednosti konteksta odrastanja i školovanja. Osnovni pristup čini Bourdieuova teorija prakse (1977.a), koja je svoje ekstenzije dobila u teoriji društvene reprodukcije (1977.b), čestoj u istraživanjima obrazovnih mogućnosti učenika različitog obiteljskog podrijetla. Prema njoj, razlike u obrazovnim postignućima vezane su uz kulturne, ekonomske i socijalne resurse učenika. Tako učenici iz obitelji s bogatijim resursima postižu bolje obrazovne rezultate, više razine obrazovanja i pohađaju prestižnije obrazovne institucije. I obrazovni sustav privilegira učenike viših društvenih klasa prepoznajući njihov kulturni kapital, te tako doprinosi održanju postojećih obrazovnih i društvenih nejednakosti (Bourdieu, 1977.b).

Bourdieuovi koncepti - ekonomski, kulturni i socijalni kapital, habitus i polje - čine plodni heuristički okvir, čija je upotreba rezultirala kompleksnim mjerama i inovativnim istraživačkim pristupima.

Ekonomski kapital znači (ne)posjedovanje financijskih resursa i materijalnih dobara i temelj je derivacije ostalih kapitala. Kulturni kapital, u osnovi, obiteljski je stečena upoznatost s dominantnom kulturom. Česte mjere uključuju obrazovni status roditelja, učeničke posjete izložbama i kazalištima, učestalost čitalačkih praksi i umjetničkih aktivnosti djece (Flere, Tavčar Krajnc, Klanjšek, Musil i Kirbiš, 2009.), ali 
i roditelja (Aschaffenburg i Mass, 1997.) te obiteljsko posjedovanje kulturnih dobara i obiteljska komunikacija (Jaeger, 2009.). Socijalni kapital resursi su koji proizlaze iz pripadnosti pojedinca grupama. U kontekstu škole shvaćan je kao informacijska podrška o mogućnostima nakon srednje škole (Stanton-Salazar i Dornbusch, 1995.). Koncepti polja i habitusa rijetko se operacionaliziraju (npr. Dumais, 2002.; Nora, 2004.). Habitus se odnosi na mentalne strukture koje se internaliziraju socijalizacijom, a određene su društvenim položajem pojedinca te usmjeravaju način na koji on razumije svijet i djeluje. Polje je socijalni prostor aktiviranja i natjecanja za kapitale, koji omogućuje reprodukciju društvenih nejednakosti. Koristi se i u odnosu na institucionalne karakteristike koje doprinose obrazovnom (ne)uspjehu, te Reay (1998., 2001.) razrađuje pojam institucionalnog habitusa kao poticaje na i/ili predrasude učitelja prema nastavku školovanja učenika.

Istraživanja s interesom za posljedice ruralnosti na geografsku i društvenu mobilnost učenika potvrdila su značaj obiteljskog kulturnog kapitala za migraciju ruralno $\rightarrow$ urbano. Za učenike iz ruralnih sredina geografska mobilnost omogućava društvenu, a veće šanse imaju oni iz viših ruralnih društvenih klasa koji usvajaju poseban urbani habitus (Rye i Blekesaune, 2003.). Različite socioekonomske pozicije učenika potiču različite percepcije mjesta i prostora (Corbett, 2007.), koje djeluju na (ne)mobilnost unutar urbano-ruralne hijerarhije i ulazak u polje urbanog društvenog sustava (Rye i Almås, 2004.).

Dakle efekti geografske lokacije povezuju silnice kulturne reprodukcije i utječu na to nastavljaju li mladi visoko obrazovanje i gdje. Uvjeti zajednica djeluju kao dispozicije kroz koje pojedinci internaliziraju objektivne strukture i oblikuju leće kroz koje vide društvo. Unutar strukture obrazovnog sistema osnova djelovanja pojedinaca jesu njihovi individualni kapitali. No i zajednice i obitelji izvor su resursa i simboličke vrijednosti (Andres i Looker, 2001.). Odlazak na studij za učenike iz ruralnih sredina geografska je i sociokulturna tranzicija, te njihove odluke uključuju značenja lokalnog, doživljaje ruralnog te vezanost za mjesto i zajednicu (Geldens, 2005.; Wiborg, 2004.; 2006.). Time su im osnovne zapreke pristupu visokom obrazovanju porast troškova preseljenjem, utjecaj značajnih drugih na dojmove o visokom obrazovanju i razlike spram akademske i/ili urbane kulture (McIlveen, Ford i Everton, 2005.).

Kako pokazuje Baranović (2015.), istraživanja socijalne dimenzije obrazovanja u Hrvatskoj ukazuju na održavanje društvenih i obrazovnih pretpostavki (re)produkcije društvenih nejednakosti u obrazovanju, i u socijalističkom i postsocijalitičkom razdoblju. No utjecaj aspekata rezidencijalnog podrijetla na obrazovne ishode nije pomnije istraživan. ${ }^{1}$ Jedno ranije istraživanje (Tomanović, 1967.) upozorilo je na nepovoljnu obrazovnu poziciju učenika iz ruralnih sredina, koju kumulativno podržavaju veće vjerojatnosti njihova odrastanja u obiteljima slabijih materijalnih i kulturnih resursa i zajednicama slabije kulturne ponude i kvalitete škola. Na potrebu obuhvaćanja aspekata nejednakosti vezanih uz regionalne razlike i pristup visokom

1 Rijetka ispitivanja razlika u uspješnosti studenata iz ruralnih/urbanih sredina ograničena su na pojedine institucije (npr. Polašek i Kolčić, 2006.). 
obrazovanju za osobe iz ruralnih ili geografski izoliranih krajeva upućuje i projekt EUROSTUDENT (Farnell i sur., 2011.).

U radu se polazi od pretpostavke da dihotomija urbano - ruralno ostaje važan način racionaliziranja suvremene stvarnosti, koja je izražena u različitim vrstama problema i obrazaca životnih iskustava ruralnih sredina u odnosu na gradske. Teoretski, prihvaća se ideja o dinamičnoj mnogostranosti oblikovanja ruralnog u međusobnom odnosu 1) konkretnog ruralnog prostora, 2) formalnih reprezentacija ruralnog u diskursu birokracije, politike, znanosti te 3) načina življenja u ruralnom (Halfacree, 2006.). Takav sveobuhvatni okvir postavlja teškoće definiranju ruralnog; ono je drugačije za drugačije aktere, s definicijama za drugačije svrhe i na osnovi drugačijih iskustava, ali i s obzirom na realne, u prostoru materijalizirane probleme. Ono što je dio povijesnog razvoja značenja ruralnog je da se ono uvijek određuje kao dio dihotomije i najjasnija značenja dobiva u odnosu na urbano (Woods, 2011.). Problem je u radu pragmatično riješen, te se za definiranje ruralnoga koristi klasifikacija realnog prostora nastala na osnovi širokog raspona statističkih indikatora za distinkciju ruralnih i urbanih naselja u Hrvatskoj (Lukić, 2012.), dok je istraživački interes fokusiran na sociokulturne karakteristike ljudi koji žive u naseljima određenih karakteristika, s pretpostavkom da to gdje ljudi žive ima utjecaj na njihov životni stil, vrijednosti, djelovanja.

Cilj je rada u hrvatskom kontekstu ispitati razlike u obrazovnim namjerama i orijentacijama učenika različitog rezidencijalnog podrijetla te opisati sociokulturne karakteristike ruralnog i urbanog polja s obzirom na strukturu resursa dostupnih učenicima različitog rezidencijalnog podrijetla, a ispituju se mjerama Bourdieuovih koncepata. Budući da je to samo jedna dimenzija utjecaja geografske lokacije na obrazovne ishode (Andres i Looker, 2001.), dodatni je cilj i ispitati elemente simboličke vrijednosti koju konteksti odrastanja i školovanja imaju za učenike različitog rezidencijalnog podrijetla. ${ }^{2}$ Radna je hipoteza da postoje razlike između učenika različitog rezidencijalnog podrijetla prema pokazateljima njihovih obrazovnih orijentacija i namjera studiranja te dostupnih resursa i simboličke vrijednosti konteksta odrastanja i školovanja.

Očekuje se potvrđivanje teze da se učenici odrasli u ruralnim sredinama u manjoj mjeri odlučuju za studiranje, s čime su u skladu i njihove obrazovne orijentacije, koje možemo smatrati indikatorima obrazovnog habitusa učenika. Stoga slijedi analiza razlika prema resursima kojima učenici imaju pristup u svojim obiteljima i školama te prema simboličkoj vrijednosti koju za učenike različitog rezidencijalnog podrijetla mogu imati ti socijalizacijski konteksti s obzirom na njihovu namjeru studiranja.

2 Širi okvir rada oblikuje predmet istraživanja fokusiran na odluke učenika koji odrastaju u ruralnim sredinama o studiranju i izborima visokog obrazovanja, odnosno na interakcije geografskih i sociokulturnih odrednica tih odluka. Osnovni je cilj ispitati utjecaj rezidencijalnog podrijetla na odluku o studiranju i izbor visokog obrazovanja učenika s pretpostavkom da je odlučivanje o visokom obrazovanju kod učenika ruralnih sredina obilježeno određenim specifičnostima. 


\section{Metodologija}

\subsection{Uzorak}

U radu su korišteni podaci prikupljeni u sklopu nacionalnog istraživačkog projekta Socijalni identiteti, pristup visokom obrazovanju i odabir studija. U svrhu ispitivanja veza društvenog podrijetla učenika i njihovih odluka o studiranju u proljeće 2014. godine provedeno je anketno ispitivanje na uzorku od 5\% hrvatskih maturanata javnih srednjih škola $(\mathrm{N}=2106){ }^{3}$

Slika 1.

Udio slavonskih maturanata različitih tipova škola u populaciji i u uzorku

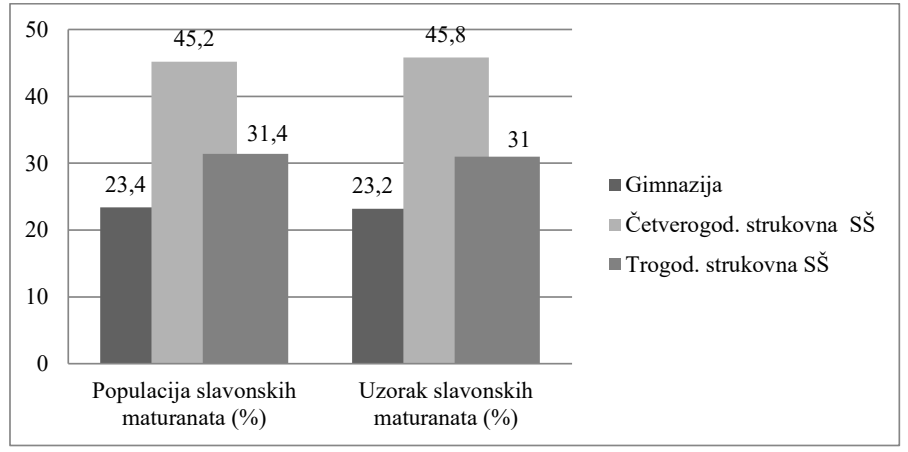

Uzorak učenika regije Slavonije ${ }^{4}$ obuhvaća 439 anketiranih učenika (21\% nacionalnog uzorka), što je reprezentativan petpostotni uzorak iz populacije slavonskih maturanata. Prema tipu škole, udjeli slavonskih učenika reprezentativni su udjelima u populaciji (slika 1.).

Rodno, udjeli mladića i djevojaka ujednačeni su (49\% - 51\%), no zastupljenost ovisi o tipu škole: više djevojaka (64\%) anketirano je u gimnazijama, dok je nešto više mladića anketirano u strukovnim školama. ${ }^{5}$

3 Projekt Socijalni identiteti, pristup visokom obrazovanju i odabir studija, koji je financirala Hrvatska zaklada za znanost, proveo je (2013. - 2016.) Institut za društvena istraživanja u Zagrebu pod vodstvom dr.sc. Branislave Baranović. Više o projektu može se naći na internetskim stranicama http://www.idi.hr/sipvoos/.

4 Čine je Osječko-baranjska, Brodsko-posavska, Požeško-slavonska, Virovitičko-podravska i Vukovarsko-srijemska županija.

5 Na kraju šk. god. 2013./14. učenica je bilo 50\%, iako je 70\% učenica u srednjim umjetničkim, $61 \%$ u gimnazijama, $48 \%$ u tehničkim i srodnim, a samo $35 \%$ u industrijskim i obrtničkim školama (Državni zavod za statistiku, 2015.). 
S obzirom na fokus rada zahvaćeno je 49\% učenika odraslih u ruralnim te $51 \%$ odraslih u urbanim slavonskim naseljima. ${ }^{6}$

Tablica 1.

Razlike između učenika različitog rezidencijalnog podrijetla prema tipu škole

\begin{tabular}{|c|c|c|c|c|c|c|c|}
\hline & \multicolumn{2}{|c|}{ Ukupno } & \multicolumn{2}{|c|}{ Ruralno } & \multicolumn{2}{|c|}{ Urbano } & \multirow{2}{*}{ Hi-kvadrat } \\
\hline & f & $\%$ & f & $\%$ & f & $\%$ & \\
\hline Tip škole & 435 & 100 & 214 & 49,2 & 221 & 50,8 & \\
\hline Gimnazija & 102 & 23,4 & 20 & 9,3 & 82 & 37,1 & \multirow{3}{*}{$\begin{array}{l}\chi^{2}(2)= \\
50,49^{*}\end{array}$} \\
\hline Četverogodišnja strukovna srednja škola & 197 & 45,3 & 106 & 49,5 & 91 & 41,2 & \\
\hline Trogodišnja strukovna srednja škola & 136 & 31,3 & 88 & 41,1 & 48 & 21,7 & \\
\hline
\end{tabular}

Na liniji urbano - ruralno uzorak je rodno ujednačen, no vidljivo je (tablica 1.) i da postoje razlike u pohađanju srednjoškolskog programa: daleko manje ruralnih učenika pohađa gimnazije (9\%), a više trogodišnje strukovne škole (2/5), dok više od 1/3 urbanih učenika završava gimnazije, a tek 1/5 trogodišnje strukovne škole.

\subsection{Korištene mjere}

\subsubsection{Rezidencijalno podrijetlo}

Učenici su odgovorom na pitanje „Gdje si proveo veći dio života prije upisa u srednju školu?" određivali svoje rezidencijalno podrijetlo samoklasifikacijom u kategorije: „na selu“, „u malom gradu“, „u velikom gradu“, „u Zagrebu“ te su upisivali i naziv mjesta odrastanja. Odgovori su kodirani: gradska naselja prema centralitetu ${ }^{7}$, a ruralna u tip naselja hrvatskog sociogeografskog prostora ${ }^{8}$. Potom je kreirana jednostavna kategorizacija: „ruralno rezidencijalno podrijetlo“ - „urbano rezidencijalno podrijetlo".

6 Prema analizi hrvatskog ruralnog prostora (Lukić, 2012.), 46\% hrvatskog stanovništva živi u ruralnim i urbaniziranim naseljima, što znači da preostalih 54\% čini gradsko stanovništvo.

${ }^{7}$ Kodovi glavni grad, makroregionalni centri, regionalni centri jači i slabiji te subregionalni centri jači i slabiji dodjeljivani su gradovima prema funkcijama koje ispunjavaju u sociogeografskom prostoru Hrvatske (Lukić, 2012.).

8 Sociogeografska analiza hrvatskog prostora ukazala je na pluralnost ruralnosti izraženoj u 7 klastera: 1) ekonomski diverzificirana, pretežito turistička, 2) dinamična, strukturno jača, 3) ostala izvangradska naselja, 4) naselja ruralne periferije, 5) naselja poljoprivredne ekstenzifikacije i slabe demografske dinamike, 6) dostupnija, ovisna o cirkulaciji i 7) tržišno orijentirana poljoprivredna ruralna i urbanizirana naselja (Lukić, 2012.). 


\subsubsection{Obrazovni ishodi i orijentacije}

Namjera studiranja učenika osnovni je obrazovni ishod, a ispitala se tako da su učenici kao odgovor na pitanje „Namjeravaš li studirati?" odabirali između: „da“, „ne“, „ne znam“.

Školski uspjeh definiran je kao opći školski uspjeh u prethodnoj godini školovanja. Učenici su upisivali odgovor s jednom decimalom.

Za mjerenje obrazovnih aspiracija učenike se pitalo koji najviši stupanj obrazovanja žele postići, a za mjerenje obrazovnih očekivanja pitani su koji najviši stupanj obrazovanja očekuju da će stvarno postići. Oboje su procjenjivali na skali: „završena srednja škola“, „završen preddiplomski studij“, „završen diplomski studij“, „Završen doktorski studij“.

Mjera podrazumijevanja studiranja učenike je tražila da izaberu tvrdnju koja se najviše odnosi na njih: „podrazumijeva mi se da ću upisati studij“, „podrazumijeva mi se da neću upisati studij“ ili „niti mi se podrazumijeva niti ne podrazumijeva da ću upisati studij".

\subsubsection{Obiteljski i školski resursi}

Ispitivani kapitali obuhvaćaju ekonomski (radni status roditelja, posjedovanje imovine i procjena financijske situacije obitelji) te kulturni kapital obitelji (obrazovanje roditelja, broj knjiga kod kuće, posjedovanje kulturnih dobara te roditeljske kulturne prakse).

Radni status roditelja. Učenici su za majku i oca određivali jesu li: „stalno zaposlen/a“, „nezaposlen/a, „zaposlen/a povremeno“, „umirovljenik/ca“, i „nešto drugo“. Za majke je postojala i opcija „domaćica“. Varijable su rekodirane, a rezultati spojeni u mjeru s kategorijama: „oboje sa stalnim prihodima“, „jedno sa stalnim prihodima“, „oboje bez stalnih prihoda“ te „oboje bez izvora prihoda“.

Posjedovanje imovine. Učenici su procjenjivali broj posjedovanih računala, automobila i nekretnina u četiri stupnja $(0=$ ni jedan, $1=$ jedan, $2=$ dva, $3=$ tri ili više $)$. Rezultat je kreiran kao zbroj vrijednosti na tim trima česticama.

Financijska situacija obitelji odnosila se na procjenu učenika na skali od pet stupnjeva: 1 = jedva spaja kraj s krajem, 2 = ima za ono što je nužno, 3 = ima dovoljno za normalan/prosječan život, 4 = prilično je dobrostojeća, 5 = bogata je.

Obrazovanje roditelja. Učenici su za majku i oca određivali stupanj obrazovanja: „nezavršena osnovna škola“, „osnovna škola“, „trogodišnja srednja strukovna škola“, „Četverogodišnja srednja strukovna škola“, „gimnazija“, „viša škola, visoka škola, veleučilište“, „fakultet, umjetnička akademija“, „magisterij ili doktorat“. Varijable su rekodirane, a rezultati za majku i oca spojeni u varijablu s kategorijama: „oboje (ne) 
završena osnovna škola“, „barem jedan roditelj sa završenom trogodišnjom strukovnom školom“, „barem jedan roditelj sa završenom četverogodišnjom srednjom školom“, „barem jedan visokoobrazovani roditelj“.

Broj knjiga kod kuće učenici su procjenjivali odabirom kategorije: „0 - 10“, „11 25“, „26 - 100“, „101 - 200“, „201 - 500“ i „više od 500 knjiga“. Naknadno je smanjen broj kategorija na tri: „0 - 25 knjiga“, „26 - 200 knjiga“ i „više od 200 knjiga“.

Posjedovanje kulturnih dobara. Učenici su bilježili imaju li kod kuće („da/ne“) „stručne knjige ili priručnike“, „knjige klasične literature“, „knjige pisane na stranom jeziku“, „umjetnička djela“ i „CD-e ili druge nosače zvuka klasične ili jazz glazbe“. Rezultat je nastao zbrajanjem vrijednosti na česticama.

Roditeljske kulturne prakse. Učenici su procjenjivali koliko često roditelji: „čitaju publicistiku“, „čitaju prozu i poeziju“, „pohađaju obrazovne tečajeve, programe ili predavanja“, „posjećuju muzeje ili umjetničke galerije“, „idu na kazališne predstave“ te „posjećuju operu, balet ili koncerte klasične glazbe“ na skali od pet stupnjeva (1 = nikad, 2 = vrlo rijetko, 3 = ponekad, 4 = često, $5=$ vrlo često). Analiza glavnih komponenti potvrdila je jednofaktorsku strukturu skale s koeficijentom unutarnje konzistentnosti $\alpha=0,84$ (Cronbach).

Karakteristike srednjih škola. Učenici su procjenjivali stupanj slaganja s osam opisa karakteristika škola na ljestvici od pet stupnjeva (od 1 = uopće se ne slažem do $5=u$ potpunosti se slažem). Analiza glavnih komponenti ukazala je na trofaktorsku strukturu (tablica 2.), a na osnovi rezultata kreirane su sumativne varijable zbrajanjem rezultata čestica koje čine pojedine faktore.

Tablica 2.

Rezultati analize glavnih komponenti instrumenta „karakteristike srednje škole“

\begin{tabular}{|l|c|l|c|}
\hline Dimenzija & Cronbachov a & Karakteristična varijabla & $\boldsymbol{\lambda}$ \\
\hline Škola visokog statusa & 0,78 & Moju je školu teško upisati & 0,96 \\
\hline Akademski poticajna škola & 0,69 & $\begin{array}{l}\text { U školi možemo dobiti informacije } \\
\text { u vezi daljnjeg obrazovanja }\end{array}$ & 0,90 \\
\hline $\begin{array}{l}\text { Opremljena škola dobrog } \\
\text { programa }\end{array}$ & 0,69 & Moja je škola dobro opremljena & $-0,87$ \\
\hline
\end{tabular}

\subsubsection{Simbolička vrijednost obitelji/zajednica}

Simbolička vrijednost obitelji/zajednica zahvaća se ispitivanjem obiteljskih poticajnih praksi, utjecajem značajnih drugih na odluku o (ne)studiranju te stavovima o zajednici odrastanja.

Obiteljske poticajne prakse. Učenici su na ljestvici od pet stupnjeva (od 1 = uopće se ne slažem do $5=\mathrm{u}$ potpunosti se slažem) određivali stupanj slaganja s četirima 
česticama koje opisuju roditeljsku pomoć pri školskim obvezama i interes za školske aktivnosti djece te njihovo ohrabrivanje studiranja ili što bržeg zaposlenja.

Utjecaj značajnih drugih na učeničku odluku o (ne)studiranju. Učenici su procjenjivali utjecaj na skali od pet stupnjeva (od $1=$ nimalo nisu utjecali do $5=$ izrazito su utjecali) za 11 osoba: „roditelji“, „braća/sestre“, „,̌lanovi šire rodbine“, „prijatelj/i“, „dečko ili cura“, „školski kolege“, „prijatelji ili poznanici roditelja“, „susjedi“ te „nastavnici“, „stručni suradnici u školi“ i „savjetnik za profesionalno usmjeravanje izvan škole“.

Simbolička vrijednost zajednica odrastanja. Za 19 čestica koje opisuju vezanost, uključenost i pripadnost te želju za doprinosom zajednici odrastanja, ali i namjere njenog napuštanja, učenici su procjenjivali stupanj slaganja na ljestvici od pet stupnjeva (od 1 = uopće se ne slažem do $5=$ u potpunosti se slažem). Nakon rekodiranja pojedinih čestica da bi smisleno bile jednako usmjerene, analiza glavnih komponenti ukazala je na trofaktorsku strukturu instrumenta s visokim koeficijentima unutarnje konzistentnosti (tablica 3.). Na osnovi rezultata kreirane su tri sumativne varijable.

Tablica 3.

Rezultati analize glavnih komponenti instrumenta „simbolička vrijednost zajednice odrastanja“

\begin{tabular}{|l|c|l|c|}
\hline \multirow{2}{*}{ Dimenzija } & Cronbachov a & Karakteristične varijable & $\boldsymbol{\lambda}$ \\
\hline \multirow{2}{*}{ Pripadnost } & 0,85 & $\begin{array}{l}\text { Rado se uključujem u aktivnosti } \\
\text { zajednice }\end{array}$ & 0,90 \\
\cline { 3 - 4 } & \multirow{2}{*}{ Ostanak } & $\begin{array}{l}\text { Svojim radom želim doprinijeti } \\
\text { zajednici }\end{array}$ & 0,88 \\
\hline \multirow{2}{*}{ Emocionalna vezanost } & $\begin{array}{l}\text { *Ne vidim budućnost u mjestu u kojem } \\
\text { živim }\end{array}$ & $\begin{array}{l}\text { *Ako želim postići nešto u životu, } \\
\text { moram se preseliti }\end{array}$ & 0,91 \\
\hline \multirow{2}{*}{0,79} & $\begin{array}{l}\text { Mjesto u kojem živim sigurna je } \\
\text { sredina za odrastanje }\end{array}$ & 0,84 \\
\cline { 3 - 4 } & $\begin{array}{l}\text { Moja životna sredina ugodno je mjesto } \\
\text { za stanovanje }\end{array}$ & $-0,89$ \\
\hline
\end{tabular}

${ }^{*}$ Rekodirane varijable

Tri koraka analiza sadrže konfirmatorne i eksploratorne elemente s obzirom na nalaze prethodnih istraživanja i upotrebu pojedinih mjera. Analitičke procedure uključuju t-test i hi-kvadrat za ispitivanje urbano-ruralnih razlika na pojedinim mjerama?, čemu su prethodile i analize faktorske strukture i metrijskih karakteristika pojedinih instrumenata.

9 Rezidencijalno podrijetlo nezavisna je varijabla u t-testu, te zavisna u hi-kvadrat analizama. 


\section{Rezultati}

\subsection{Obrazovni ishodi i orijentacije učenika različitog rezidencijalnog podrijetla}

Postoje li razlike između učenika koji odrastaju u ruralnim i urbanim naseljima s obzirom na njihov školski uspjeh i namjeru studiranja te prema njihovim obrazovnim orijentacijama shvaćenima kao obrazovne aspiracije, očekivanja i podrazumijevanje studiranja? Statistički značajni testovi potvrdili su konzistentan obrazac urbano-ruralnih razlika (slika 2.).

Slika 2.

Razlike između učenika različitog rezidencijalnog podrijetla prema namjeri studiranja i obrazovnim orijentacijama ${ }^{10}$

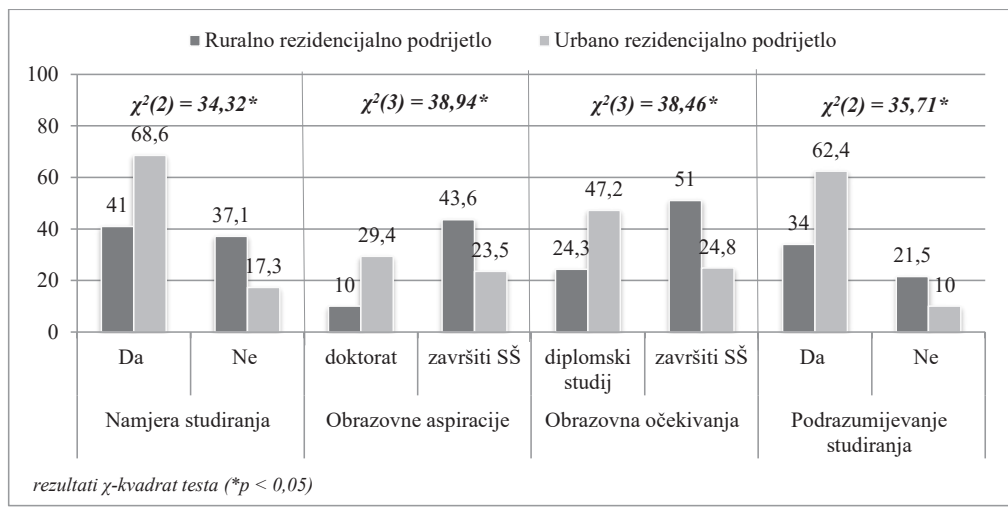

Učenici urbanog rezidencijalnog podrijetla u daleko se većem broju odlučuju za studiranje (69\% nasuprot 41\% učenika ruralnog rezidencijalnog podrijetla), najveći broj $(2 / 3)$ ih aspirira na najviše stupnjeve obrazovanja - na završavanje diplomskog i doktorskog studija (nasuprot $40 \%$ učenika ruralnog rezidencijalnog podrijetla), a preko polovice i očekuje da će im se to ostvariti. Nadalje, gotovo $2 / 3$ ih smatra da im se studiranje podrazumijeva, dok isto smatra tek $1 / 3$ učenika odraslih u ruralnim naseljima.

S druge strane, veći broj učenika odraslih u ruralnim naseljima ne namjerava studirati i još nije donijelo odluku (59\% nasuprot 31\% odraslih u urbanim naseljima), 44\% ih želi samo završiti srednju školu (nasuprot 1/4 učenika urbanog rezidencijalnog podrijetla), a polovica i očekuje da će taj stupanj obrazovanja postići, što je kategorija koja za njih najviše raste u odnosu na njihove aspiracije (dok se za učenike urbanog rezidencijalnog podrijetla gotovo uopće ne povećava) (slika 3.). Konačno, najveći broj učenika ruralnog rezidencijalnog podrijetla smatra da im se studiranje niti podrazumijeva niti ne podrazumijeva ( $45 \%$ nasuprot $28 \%$ učenika odraslih u urbanim naseljima).

10 Grafički su prikazani udjeli učenika u kategorijama nezavisnih varijabli koje pokazuju najveće razlike. 
S tim su u skladu prethodno opisani podaci urbano-ruralnih razlika s obzirom na tip srednje škole koje učenici pohađaju (tablica 1.) te podaci o ruralno-urbanim razlikama u školskom uspjehu (tablica 4.).

Tablica 4.

Razlike između učenika različitog rezidencijalnog podrijetla prema školskom uspjehu

\begin{tabular}{|c|c|c|c|c|c|c|c|}
\hline \multirow[b]{2}{*}{ Zavisna varijabla } & \multicolumn{2}{|c|}{ Ukupno } & \multicolumn{2}{|c|}{$\begin{array}{l}\text { (1) Ruralno } \\
\text { rezidencijalno } \\
\text { podrijetlo }\end{array}$} & \multicolumn{2}{|c|}{$\begin{array}{l}\text { (2) Urbano } \\
\text { rezidencijalno } \\
\text { podrijetlo }\end{array}$} & \multirow{2}{*}{ t-test } \\
\hline & M & SD & M & SD & M & SD & \\
\hline Opći školski uspjeh & 3,63 & 0,65 & 3,57 & 0,68 & 3,69 & 0,61 & $\mathrm{t}(430)=\mathbf{- 1}, \mathbf{9 7 ^ { * }}$ \\
\hline
\end{tabular}

Viši opći školski uspjeh na kraju prethodnog razreda statistički značajno razlikuje učenike urbanog i ruralnog rezidencijalnog podrijetla.

Slika 3.

Usporedni prikaz udjela učenika različitog rezidencijalnog podrijetla u kategorijama obrazovnih aspiracija i očekivanja

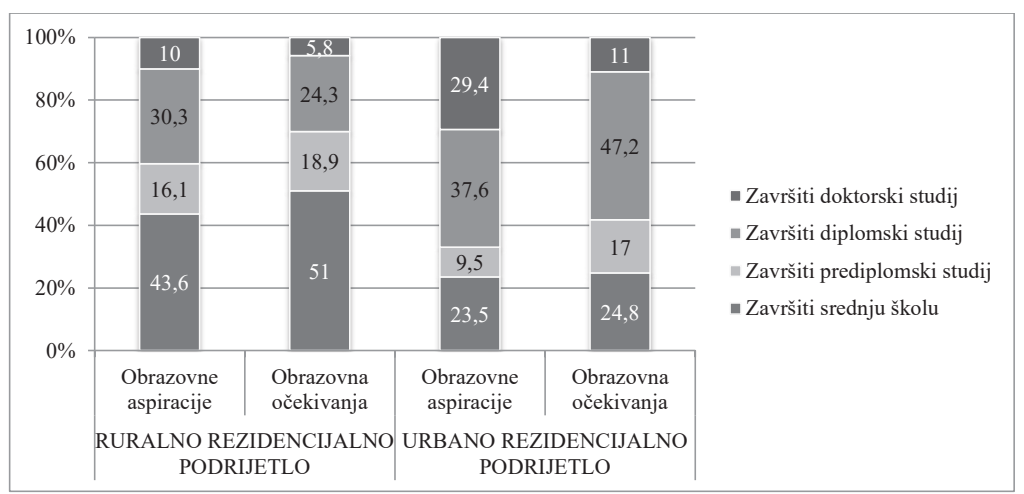

\subsection{Obiteljski resursi učenika različitog rezidencijalnog podrijetla}

Prethodne analize ukazuju na važnost ispitivanja socijalizacijskih konteksta u kojima učenici žive i školuju se. Stoga se ispituju ruralno-urbane razlike među učenicima s obzirom na strukturu ekonomskih i kulturnih resursa kojima imaju pristup.

$\mathrm{Na}$ svim operacionalnim mjerama Bourdieuovih koncepata statistički značajni testovi potvrdili su postojanje ruralno-urbanih razlika i ukazali na nepovoljniju strukturu obiteljskih kapitala učenika ruralnog rezidencijalnog podrijetla (slika 4. i tablica 5.). 
Slika 4.

Razlike između učenika različitog rezidencijalnog podrijetla prema elementima obiteljskih resursa ${ }^{11}$

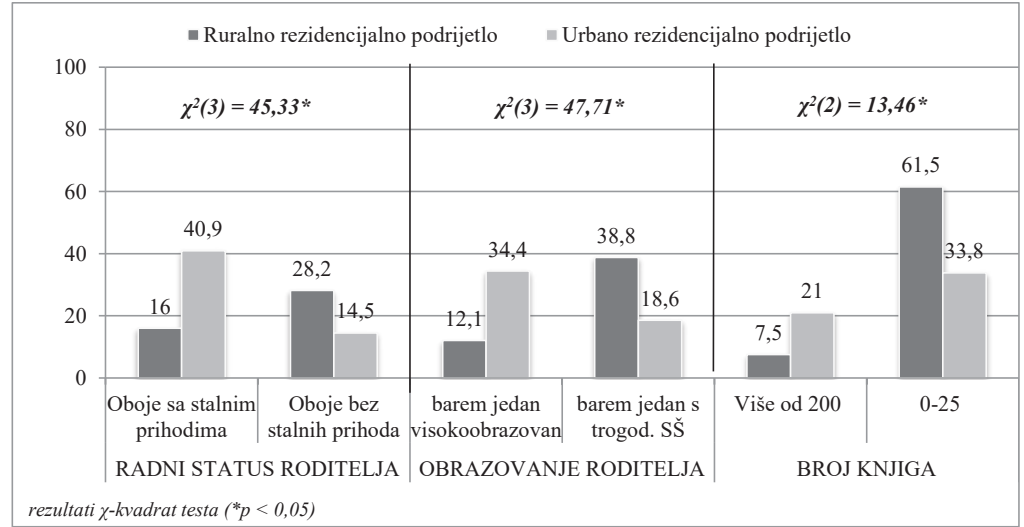

Tablica 5.

Razlike između učenika različitog rezidencijalnog podrijetla na elementima obiteljskih kapitala

\begin{tabular}{|c|c|c|c|c|c|}
\hline \multirow[b]{2}{*}{ Zavisna varijabla } & \multicolumn{2}{|c|}{$\begin{array}{l}\text { (1) Ruralno } \\
\text { rezidencijalno } \\
\text { podrijetlo }\end{array}$} & \multicolumn{2}{|c|}{$\begin{array}{l}\text { (2) Urbano } \\
\text { rezidencijalno } \\
\text { podrijetlo }\end{array}$} & \multirow[t]{2}{*}{ t-test } \\
\hline & M & SD & M & SD & \\
\hline Posjedovanje imovine & 1,39 & 0,54 & 1,64 & 0,55 & $t(429)=-4,62^{*}$ \\
\hline Procjena financijske situacije & 2,75 & 0,81 & 2,98 & 0,73 & $\mathrm{t}(413,0)=\mathbf{- 3}, \mathbf{0 1} *$ \\
\hline Posjedovanje kulturnih dobara & 0,54 & 0,29 & 0,68 & 0,26 & $\mathrm{t}(431)=-\mathbf{5}, 26^{*}$ \\
\hline Roditeljske kulturne prakse & 1,56 & 0,61 & 1,92 & 0,75 & $\mathrm{t}(417,2)=\mathbf{- 5 , 4} 7^{*}$ \\
\hline
\end{tabular}

Samo 16\% učenika ruralnog rezidencijalnog podrijetla ima oba roditelja sa stalnim prihodima (nasuprot 41\% odraslih u urbanim naseljima), a čak 28\% ima oba roditelja bez stalnih prihoda (nasuprot 15\% učenika urbanog rezidencijalnog podrijetla). I materijalno, statistički im je značajno niži prosječni rezultat posjedovanja računala, automobila i nekretnina, a prosječno slabijim procjenjuju i financijsku situaciju obitelji.

Razlike između učenika različitog rezidencijalnog podrijetla potvrđuju se i prema svim promatranim kulturnim karakteristikama obitelji. Samo 12\% učenika odraslih u ruralnim naseljima (nasuprot 1/3 odraslih u urbanim naseljima) ima visokoobrazovanog roditelja, dok ih se gotovo polovica (48\%) nalazi u kategorijama najnižih stupnjeva roditeljskog obrazovanja (do trogodišnjeg strukovnog). Značajno rjeđim učenici ruralnog rezidencijalnog podrijetla procjenjuju i roditeljsko čitanje, pohađanje obrazovnih tečajeva i kulturnih događanja. Također, njihova prosječna vrijednost

11 Grafički su prikazani udjeli učenika u kategorijama nezavisnih varijabli koje pokazuju najveće razlike. 
posjedovanja različitih kulturnih dobara značajno je niža od one učenika odraslih u ruralnim naseljima, a gotovo $2 / 3$ ih procjenjuje da kod kuće ima samo do 25 knjiga (nasuprot $1 / 3$ učenika urbanog rezidencijalnog podrijetla).

\subsection{Rezidencijalno podrijetlo učenika i karakteristike srednje škole}

Prema Bourdieuu, osnova je društvene reprodukcije prepoznavanje kapitala učenika viših društvenih klasa u obrazovnom polju, odnosno njihovo potvrđivanje u školama, koji se tamo iskazuju kao bolji obrazovni uspjeh. Iz tog razloga eksploratorno orijentirana analiza ispituje urbano-ruralne razlike prema procjeni statusa, akademski poticajne klime te opremljenosti i izvannastavne programske ponude srednjih škola koje učenici pohađaju. Rezultati su prikazani na slici 5.

Slika 5.

Razlike između učenika različitog rezidencijalnog podrijetla prema procjenama karakteristika srednjih škola

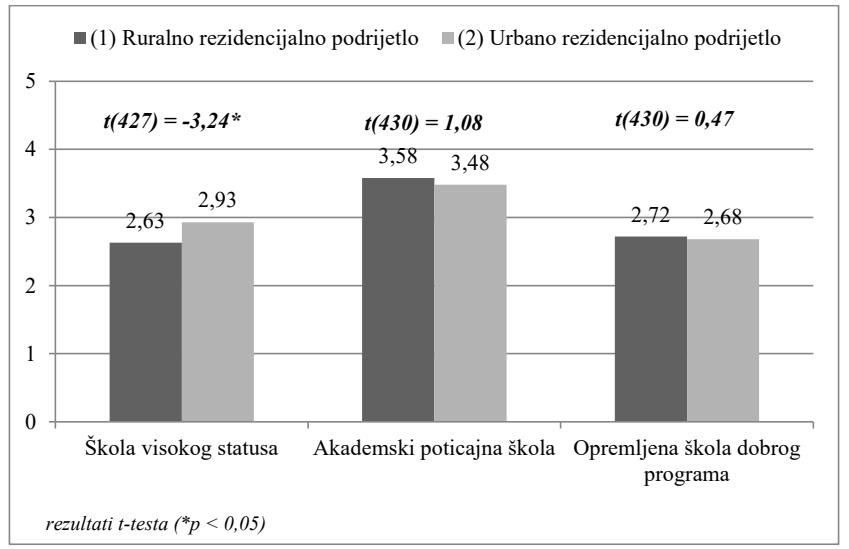

Učenici svojim školama, i bez obzira na rezidencijalno podrijetlo, sve navedene karakteristike procjenjuju prosječnima, pri čemu je poticanje i informiranje za studiranje karakteristika koju u svojim školama prepoznaje najveći broj učenika. Ipak, statistički značajne razlike pokazuju se kada je u pitanju procjena statusa škola koje pohađaju. Učenici odrasli u urbanim naseljima u većem stupnju svoje škole procjenjuju školama visokog statusa u odnosu na one ruralnog rezidencijalnog podrijetla, što objašnjava nalaz da oni i u većoj mjeri pohađaju gimnazije.

\subsection{Simbolička vrijednost obitelji, škola, zajednica za učenike različitog rezidencijalnog podrijetla}

Posljednja eksploratorno orijentirana analiza pokušava odgovoriti na pitanja o simboličkoj vrijednosti obitelji/zajednica za specifične skupine učenika kako bi se zahvatili dodatni aspekti odrastanja i školovanja učenika. 
Simbolički značaj obiteljskog konteksta ispitan je u četirima aspektima poticajnih praksi roditelja. No samo su se prema jednom pokazale statistički značajne ruralnourbane razlike (slika 6.).

Slika 6.

Razlike između učenika različitog rezidencijalnog podrijetla u procjenama aspekata roditeljskih poticaja

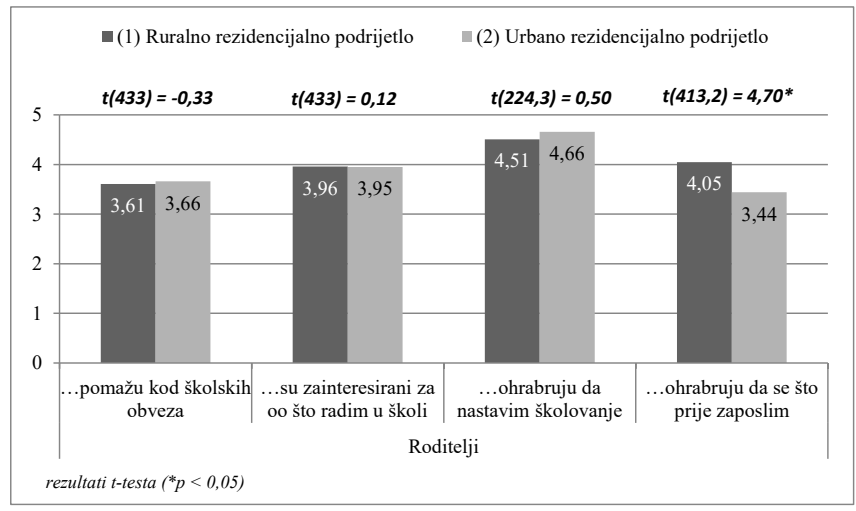

Učenici su se iznadprosječno slagali s tim da im roditelji pomažu u izvršavanju školskih obveza i da se interesiraju za njihove školske aktivnosti, a u najvećoj mjeri procjenjuju da ih roditelji ohrabruju na nastavak školovanja ${ }^{12}$. Roditeljsko ohrabrenje brzog zaposlenja učenika pak oblik je poticaja koji roditelji u najmanjoj mjeri izražavaju $^{13}$ i koji je izraženiji u obiteljima iz ruralnih naselja. Ti nalazi dijelom su u skladu s nalazima o ruralno-urbanim razlikama u obrazovnim dispozicijama učenika. Učenici ruralnog rezidencijalnog podrijetla koji su u većoj mjeri orijentirani stjecanju struke, također se u većoj mjeri potiču na zapošljavanje u obiteljskom kontekstu, ali isto tako poticaj roditelja za studiranje ne razlikuju učenike različitog rezidencijalnog podrijetla i visoko je procijenjen.

Kada se učenike pitalo koje su osobe utjecale na njihovu odluku o namjeri studiranja, pokazalo se da učenici nisu skloni pripisivati značajan utjecaj drugim osobama i tek nešto veći utjecaj daju roditeljima (57\% procjenjuje da su utjecali i izrazito utjecali). Ostalim je osobama daleko manji broj učenika pripisao značajan utjecaj ${ }^{14}$, a najmanje susjedima, stručnim suradnicima u školi i savjetniku za profesionalno usmjeravanje.

12 88\% učenika slaže se i u potpunosti se slaže s tvrdnjom „Roditelji me ohrabruju da nastavim školovanje.".

13 55\% učenika ne slaže se i uopće se ne slaže s tvrdnjom „Roditelji me ohrabruju da se što prije zaposlim.".

14 Visok utjecaj na odluku o nastavku školovanja (utjecali i izrazito utjecali) za braće/sestre procjenjuje $31 \%$ učenika, za prijatelje $28 \%$, za nastavnike $26 \%$, a slijede školske kolege, članovi šire rodbine, dečko/cura (22\%) i prijatelji/poznanici roditelja (16\%). 
No prema utjecaju pojedinačnih osoba iz različitih učeničkih krugova postoje značajne ispitivane urbano-ruralne razlike (slika 7.).

Slika 7. ${ }^{15}$

Razlike između učenika različitog rezidencijalnog podrijetla u procjenama utjecaja značajnih drugih na njihovu odluku o studiranju

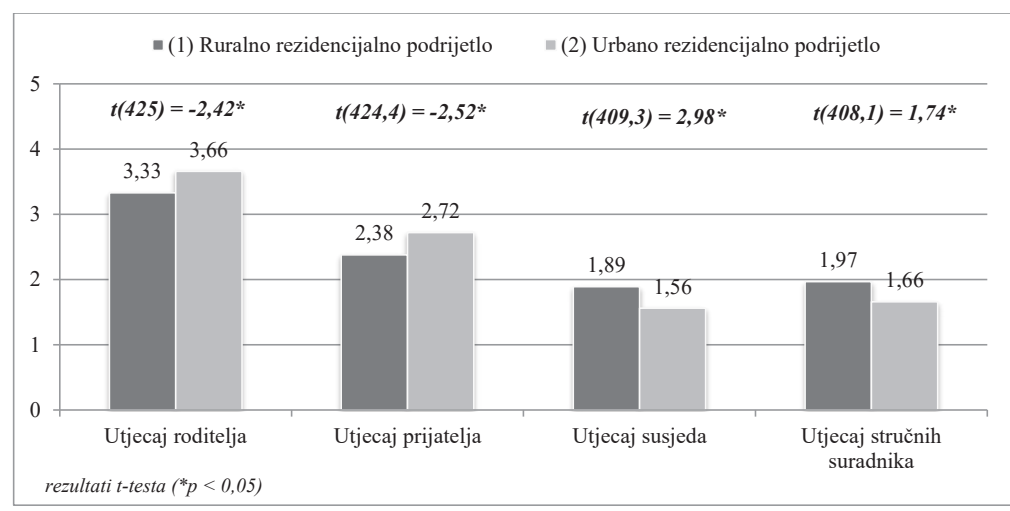

Utjecaj roditelja višim procjenjuju učenici urbanog rezidencijalnog podrijetla. Povežemo li to s prethodnim analizama, pokazuje se važnost roditelja pri usmjeravanju prema visokom obrazovanju, ali koja je šira od same uključenosti u školske aktivnosti djece, te poticanja studiranja, pri čemu su obitelji učenika jednako poticajne bez obzira na rezidencijalno podrijetlo. Također, urbani učenici višim procjenjuju utjecaj svojih prijatelja na odluku o studiranju. Time značajno viši utjecaj na odluku o studiranju učenika urbanog rezidencijalnog podrijetla imaju bliske osobe obiteljskog i prijateljskog kruga.

S druge strane, iako im se pripisuje slab utjecaj na odluku o studiranju, utjecaj susjeda i stručnih suradnika u školi snažniji je u slučaju odluka učenika ruralnog rezidencijalnog podrijetla. Analiza ukazuje na to da za učenike koji odrastaju u ruralnim naseljima, i čija je struktura obiteljskih i školskih resursa nepovoljnija, osobe iz institucionalnog školskog te bližeg životnog okruženja (susjedstvo) mogu biti važan socijalni resurs za nastavak školovanja.

U konačnici, očekivano su se potvrdile i razlike kod učenika različitog rezidencijalnog podrijetla prema stavovima o zajednici odrastanja (slika 8.).

Općenito, želja za ostankom najslabije je izražena dimenzija među učenicima, dok je najsnažnija emocionalna vezanost sa zajednicom odrastanja. Obje dimenzije pokazuju i statistički značajne ruralno-urbane razlike. Emocionalna vezanost za zajednicu odrastanja i želja za ostankom snažnije je izražena kod učenika odraslih u ruralnim naseljima.

15 Prikazuju se samo rezultati statistički značajnih testova. 
Slika 8.

Razlike između učenika različitog rezidencijalnog podrijetla na dimenzijama simboličke vrijednosti zajednice odrastanja

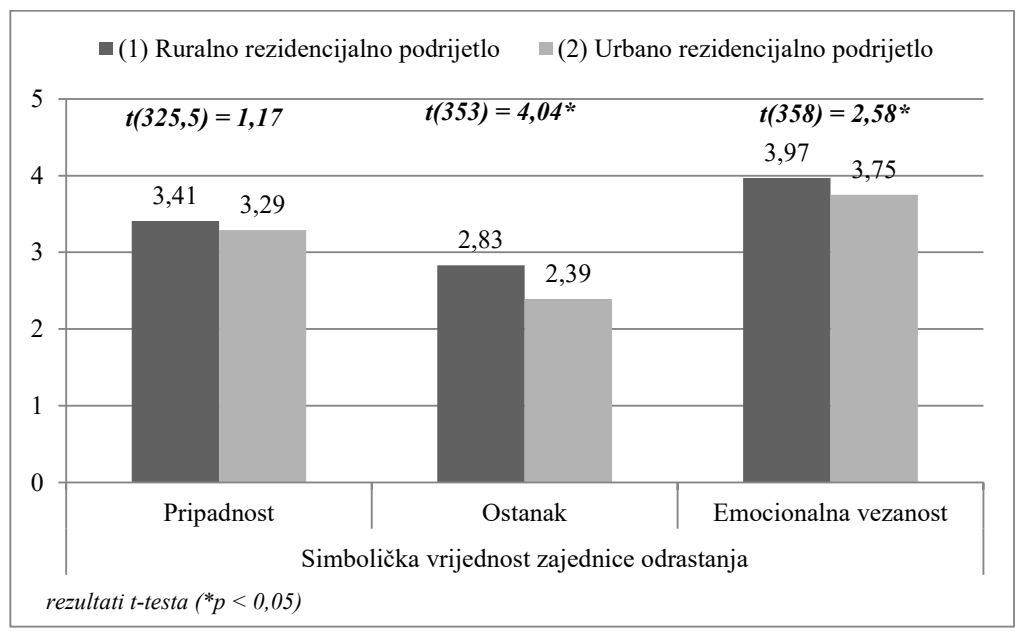

Osjećaj pripadnosti pak ne pokazuje razlike među učenicima različitog rezidencijalnog podrijetla; učenici izražavaju podjednaku razinu uključenosti u aktivnosti zajednice, međusobnog pomaganja njenih članova te želje za budućim doprinosom (radom i/ili obrazovanjem) zajednici odrastanja.

\section{Zaključna razmatranja}

Cilj rada bio je u hrvatskom kontekstu ispitati obrazovne namjere i individualne orijentacije učenika različitog rezidencijalnog podrijetla te opisati karakteristike ruralnog i urbanog polja s obzirom na strukturu resursa dostupnih učenicima različitog rezidencijalnog podrijetla. Dodatno, ispitane su i razlike prema simboličkoj vrijednosti koju konteksti odrastanja i školovanja imaju za učenike različitog rezidencijalnog podrijetla. Analize su potvrdile konzistentan obrazac urbano-ruralnih razlika.

Prve analize pokazale su da je orijentiranost prema visokom obrazovanju vjerojatnija za učenike urbanog rezidencijalnog podrijetla, koji u većoj mjeri i pohađaju gimnazije, imaju bolje ocjene, više obrazovne aspiracije, podrazumijevanje studiranja i veća očekivanja postizanja visokog obrazovanja. Za ruralne učenike pak vjerojatnija je orijentiranost prema stjecanju struke, niže ocjene, odluka o nestudiranju, kao i nepodrazumijevanje studiranja te veće percipirane prepreke u postizanju visokog obrazovanja. S osloncem u Bourdieuovoj teoriji, ispitivane obrazovne orijentacije učenika moguće je shvatiti kao indikacije osobnih habitusa učenika (Dumais, 2002.). Habitus predstavlja socijalizacijom internalizirane mentalne strukture određene društvenim položajem pojedinca, koje usmjeravaju njegove načine razumijevanja i djelovanja. Stoga je navedene rezultate moguće interpretirati kao razlike u habitusom oblikovanim obrazovnim dispozicijama učenika različitog rezidencijalnog podrijetla, što interes usmjerava na karakteristike socijalizacijskih okruženja života i školovanja učenika. 
Struktura kulturnih i ekonomskih resursa socijalizacijskog okruženja obitelji ukazuje na nepovoljniju strukturu obiteljskih kapitala ruralnih učenika. Za njihove je roditelje vjerojatniji slabiji radni, imovinski, financijski i obrazovni status te niže razine posjedovanja kulturnih dobara i rjeđe kulturne aktivnosti. Na simboličkoj dimenziji, u skladu s takvom strukturom, roditeljski poticaji na zaposlenje značajniji su kod učenika ruralnog rezidencijalnog podrijetla, dok je općeniti roditeljski utjecaj kod donošenja odluke o studiranju snažnije izražen kod onih urbanog rezidencijalnog podrijetla. Kako razlike nisu utvrđene prema roditeljskom ohrabrivanju studiranja, koje svi učenici procjenjuju visokima, kao ni prema roditeljskoj uključenosti u školske aktivnosti djece, sugerira se da se mogući doprinos objašnjenju urbano-ruralnih razlika u namjeri studiranja nalaze u drugim aspektima obiteljskog konteksta (npr. obrazovanje roditelja, dostupni resursi) koji u većoj mjeri oblikuju poticajno socijalizacijsko okruženje za učenike urbanog rezidencijalnog podrijetla.

No, kako naglašava Bourdieu, da bi se razumjele obrazovne razlike potrebno je promatrati i obrazovni sustav. Tomanović (1967.) izdvaja opremljenost škola i sposobnost učitelja kao institucionalne faktore koji podržavaju nepovoljnije obrazovne mogućnosti učenika iz ruralnih sredina. U ovdje provedenim analizama status se škole pokazao kao institucionalna karakteristika s najizraženijim urbano-ruralnim razlikama, a procjena višeg statusa škola viša je kod učenika urbanog rezidencijalnog podrijetla, koji u većoj mjeri pohađaju gimnazije. U Hrvatskoj institucionalne karakteristike srednjoškolskog obrazovanja ogledaju se u dualnoj, hijerarhijskoj strukturi statusa škola utemeljenoj u razlikovanju općeg i strukovnog obrazovanja (Baranović, 2015.). Time se škole pojavljuju kao mehanizam društvene selekcije koji regulira pristup visokom obrazovanju (Baranović, 2015.), stavljajući učenike gimnazija u povoljniju poziciju od učenika strukovnih škola, a odluka o upisu srednje škole postaje ključni trenutak daljih obrazovnih putova i moguća prepreka ulasku u visoko obrazovanje za učenike odrasle u ruralnim naseljima, koji u većoj mjeri pohađaju strukovne škole. U takvoj strukturi, analize potvrđuju, stručni suradnici u školama mogu biti važan socijalni resurs učenicima ruralnih sredina kada je u pitanju njihova namjera studiranja.

Konačno, i širi je kontekst izvor resursa i simboličke vrijednosti s obzirom na učeničku namjeru studiranja; za učenike ruralnog rezidencijalnog podrijetla susjedi mogu biti važan socijalni resurs usmjeravanja prema visokom obrazovanju, a možda i značajan (kompenzacijski) mehanizam utjecaja iz neposredne okoline. Na općenitijoj razini, učenici odrasli u ruralnim naseljima u većoj mjeri vide mogućnost budućeg života u mjestu odrastanja i nepotrebnost preseljenja te u većoj mjeri doživljavaju svoju zajednicu kao sigurnu za odrastanje i ugodnu za život zbog njenih sociokulturnih elemenata (veza, vrijednosti, načina života) i prirodnog okruženja. Doolan (2009.) je ukazala na to da emocionalna vezanost za prostor odrastanja ima utjecaj na iskustva studiranja. Nalazi daju osnovu za postavljanje teze o mogućem utjecaju tih aspekata pri izabiranju visokog obrazovanja kod učenika različitog rezidencijalnog podrijetla. Preseljenje zbog studija za učenike koji odrastaju u ruralnim sredinama dio je procesa u kojem svijest o potrebi za preseljenjem može stvarati veći konflikt između odluke o migriranju i obrazovanju, te posljedično može djelovati i većim obrazovnim barijerama (Irvin, Byun, Meece, Farmer i Hutchins, 2012.; Hektner, 1995.). 
Rezultati upućuju na bitne smjerove budućih istraživanja o doprinosu rezidencijalnog podrijetla na odluke učenika o visokom obrazovanju, kao i o doprinosu simboličke vrijednosti zajednice odrastanja u objašnjenju izbora visokog obrazovanja kod učenika.

\section{Literatura}

1. Anchaffenburg, K. and Mass I. (1997). Cultural and Educational Careers: the Dinamics of Social Reproduction. American Sociological Review, 62: 573-587.

2. Andres L. and Looker D. (2001). Rurality and Capital: Educational Expectatons and Attainments of Rural, Urban/Rural and Metropolitan Youth. The Canadian Journal of Higher Education, 31 (2): 1-46.

3. Baranović, B. (2015). Razvoj i socijalna dimenzija visokog obrazovanja u Hrvatskoj, u: Baranović, B (Ur.). Koji srednjoškolci namjeravaju studirati? Pristup visokom obrazovanju i odabir studija. Zagreb: Institut za društvena istraživanja u Zagrebu.

4. Bourdeiu, P. (1977a). Outline of a Theory of Practice. Cambridge: Cambridge University Press.

5. Bourdieu, P. (1977b). Cultural Reproduction and Social Reproduction, in: J. Karabel, J. and Halsey, A. H. (Eds.). Power and Ideology in Education. New York: Oxford University Press.

6. Bourdieu, P. (1997). The Forms of Capital, in: Halsey A. H.; Lauder, H.; Brown, P.; Stuart Wells, A. (Eds.). Education: Culture, Economy, and Society. Oxford: Oxford University Press.

7. Bracken, E. (2007). Off the Beaten Path: Rural Students and the Pursuit of Higher Education. Sociology Honors Projects. Paper 9. Pregledano 14. lipanj 2015. (http://digitalcommons.macalester.edu/soci honors/9)

8. Corbett, M. (2007). Travels in space and place: identity and rural schooling. $\mathbf{C a}$ nadian Journal of Education, 30 (3): 771-792.

9. Državni zavod za statistiku. (2015). Priopćenje: Srednje škole. Kraj šk. g. 2013./2014. i početak šk. g. 2014./2015. Zagreb: Državni zavod za statistiku.

10. Dumais, S. A. (2002). Cultural Capital, Gender, and School Success: The Role of Habitus. Sociology of Education, 75: 44-68.

11. Farnell, T.; Doolan, K.; Matković, T.; Cvitan, M. (2011). Socijalna i ekonomska slika studentskog života u Hrvatskoj. Nacionalno izvješće istraživanja EUROSTUDENT za Hrvatsku Zagreb: IRO.

12. Flere, S.; Tavčar Krajnc, M.; Klanjšek, R.; Musil, B.; Kirbiš, A. (2010). Cultural Capital and Intellectual Ability as Predictors of Scholastic Achievment: a Study of Slovenian Secondary School Students. British Journal of Sociology of Education, 31 (1): 47-58.

13. Geldens, P. (2005). Wanted: 'Place' To fill vacancy in roomy, well appointed 'space' within youth sociology. Available immediately. Proceedings of the TASA Conference 2005, University of Tasmania, 6-8 December. Pregledano 12. prosinca 2015. (https://www.google.hr/url?sa=t\&rct=j\&q=\&esrc=s\&source=web\&cd =1\&ved=0ahUKEwi1mOrF9aHKAhWC3SwKHUD3AScQFggcMAA\&url=http $\% 3 \mathrm{~A}$

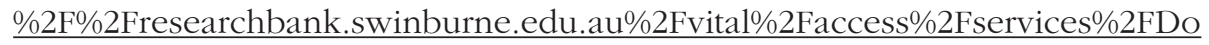


wnload\%2Fswin\%3A6074\%2FSOURCE3\&usg=AFQjCNFvCeJOqJYP7qPe9hMKH 2JLoKYYzg\&bvm=bv.111396085, d.bGg\&cad=rja).

14. Halfacree, K. (2006). Rural Space: Constructing a Three-fold Arhitecture, in: Cloke, P.; T Marsden, T. and P Mooney, P. (Eds.). Handbook of rural studies. London: SAGE.

15. Hektner, J. M. (1995). When moving up implies moving out: rural adolescent conflict in the transition to adulthood. Journal of Research in Rural Education, 11 (1): 3-14.

16. Herzog, M. J. R. and Pittman, R. B. (1995). Home, family and community: ingredients in the rural education equation. Phi Delta Kappan, 77: 113-118. Pregledano 08. lipnja 2015. (http://www.socresonline.org.uk/5/4/reay.html).

17. Hu, S. (2003). Educational Aspirations and Postsecondary Access and Choice: Students in Urban, Suburban, and Rural Schools Compared. Pregledano 08. lipnja 2015. (http://epaa.asu.edu/ojs/article/view/242).

18. Irvin, M. J.; Byun, S.; Meece, J. L.; Farmer, T. W. and Hutchins, B. C. (2012). Educational barriers of rural youth: relation if individual and contextual difference variables. Journal of Career Assessment, 20 (1): 71-87. Pregledano 16. lipnja, 2015. (http://www.ncbi.nlm.nih.gov/pmc/articles/PMC3902127/).

19. Jaeger, M. M. (2009). Equal access but unequal outcomes: cultural capital and educational choice in a meritocratic society. Social Forces, 87 (4): 1943-1971.

20. Lukić, A. (2012). Mozaik izvan grada - tipologija ruralnih i urbaniziranih naselja Hrvatske. Samobor: Meridijani.

21. McIlveen, P.; Ford, T. and Everton, B. (2005). Facilitating Transition from Rural Schools to University: A Case Study, ACER. Australian Journal of Career Development, 14 (1): 11-18.

22. Nora, A. (2004). The Role of Habitus and Cultural Capital in Choosing a College, Transitioning From High School to Higher Education, and Persisting in College Among Minority and Nonminority Students. Journal of Hispanic Higher Education, 3 (2): 180-208.

23. Polašek, O. and Kolčić, I. (2006). Academic Performance and Scientific Involvement of Final Year Medical Students Coming from Urban and Rural Backgrounds. Rural Remote Health, 21: 346-50. Pregledano 10. rujan 2015. (http:// www.ncbi.nlm.nih.gov/pubmed/16623619).

24. Puzić, S. i Košutić, I. (2015). Sociološki pristupi razumijevanju društvenih nejednakosti u obrazovanju, u: Baranović, B (Ur.). Koji srednjoškolci namjeravaju studirati? Pristup visokom obrazovanju i odabir studija. Zagreb: Institut za društvena istraživanja u Zagrebu.

25. Reay, D. (1998). 'Always Knowing' and 'Never Being Sure': Familial and Institutional Habituses and Higher Education Choice. Journal of Education Policy, 13 (4): 519-529.

26. Reay, D.; David, M. and Ball, S. (2001). 'Making a Difference?: Institutional Habituses and Higher Education Choice'. Sociological Research Online, 5 (4). (https://www.researchgate.net/publication/24131803_Making_a_Difference_Institutional Habituses and Higher Education Choice).

27. Rye, J. F. and Almås, R. (2004). Social stratification and changing division of labour in rural Norway, Paper no 2/04, ISSN 1503-2736, Paper presented at the XI World Congress in Rural Sociology, Trondheim - Norway, July 25.- 
30. 2004. Pregledano 10. rujan 2015. (https://www.researchgate.net/publication/253998886 Social stratification and changing division of labour in rural Norway).

28. Rye, J. F. and Blekesaune, A. (2003). Class and rural to urban migration, Paper to the 43th European Congress of the Regional Science Association, Jyväskylä, Finland, August 17-30, 2003. Pregledano 13. prosinac 2015. (https://www.google.

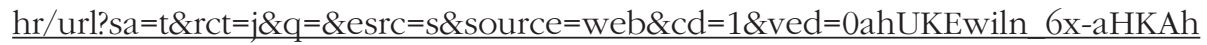
XLCCwKHZ5vCDYQFggeMAA\&url=https\%3A\%2F\%2Fwww.jyu.fi\%2Fersa2003\% 2Fcdrom\%2Fpapers\%2F267.pdf\&usg=AFQjCNFlrJt2M2sYQqOx3plvcYNEkMnXt A\&bvm=bv.111396085, d.bGg\&cad=rja).

29. Stanton-Salazar, R. D. and Dornbusch, S. M. (1995). Social Capital and the Reproduction of Inequality: Information Networks among Mexicanorigin High School Students. Sociology of Education, 68: 116-135.

30. Tomanović, V. (1967). Socijalne nejednakosti uslova za obrazovanje. Gledišta, 8 (5): 675-690.

31. Wiborg, A. (2004). Place, Nature and Migration: Students' Attachment to their Rural Home Places. Sociologia Ruralis, 44 (4): 416-432.

32. Wiborg, A. (2006). Mobility and Migration - Markers of Distinction? Rural Students' Attitudes to Migration and Home Place in Norway, in: Martti Muukkonen, M. and Sotkasiira, T. (Ur.). Young People at the Crossroads. Proceedings of the 5th International Youth Research Conference in Karelia, Petrozavodsk, September, 2006. Pregledano 12.12.2015. (http://epublications.uef.fi/pub/URN_NBN fi joy-20070186/URN NBN fi joy-20070186.pdf).

33. Woods, M. (2011). Rural. Key ideas in rural geography. Oxon/New York: Routledge. 


\title{
Different Residential Origin of Students and their Intention to Study - Capital and the Symbolic Value of the Family and the Community where One Grew Up
}

\begin{abstract}
Education is one of the main mechanisms for upward social and geographical mobility for students from rural areas. Studies in the countries with great rural areas recorded dynamic educational trends along with the demographic and economic ones. The comparison of students from rural/urban areas on different educational outcomes indicate that students from rural areas have lower aspirations and test scores, and in smaller numbers start the four-year study and graduate. However, the question of whether and how rurality contributes to unequal educational opportunities remains open. The main objective of the paper is to examine the differences in educational outcomes and orientation for students of different residential origin in the Croatian context. Furthermore, the role of rurality is discussed in search of possible explanations for found differences. The frame of Bourdieu's theory of practice, consisting of concepts of cultural, social, economic capital, habitus and field, is expanded by the interest in spatial inequalities of educational opportunities with respect to the students' residential origin. The particular emphasis is placed on examining the symbolic value that the family, school and the growing up community contexts have for students. The work includes a descriptive and comparative analysis (chi-square, t-test) of the survey data collected in the spring of 2014 on a representative sample of the graduates of three- and four-year high schools in the region of Slavonia $(\mathrm{N}=439)$. The analysis confirms the assumed urban-rural differences in the students' intention to study, their educational orientation as well as various levels of available cultural and economic capital. It also confirms the importance of the growing up and schooling context for students of different residential origin.
\end{abstract}

Key words: residential origin, educational opportunities, urban-rural differences, the students' capital, the symbolic value of the family/community of growing up. 